\title{
Creating an ICT Based Environment that Supports Creativity, Innovation and Entrepreneurship in Kosovo
}

\author{
Edmond Beqiri \\ University of Peja "Haxhi Zeka" \\ Adem Tolaj \\ Doctoral Student, European University in Tirana \\ Napolon Beqiri \\ Doctoral Student, South East European University
}

Doi:10.5901/ajis.2015.v4n2s1p23

\begin{abstract}
This paper will contribute on preparatory model of creating a sustainable ICT environment for continues motivation of Intrapeneurs to support and encourage their creativity in order to lead to innovative projects inside and outside of the organizational effectiveness of Small and Medium Enterprises (SME). The research of the paper is focused on the comparative model of this managerial issue between the models in EU and Kosovo which is part of South-East European Countries (SEE). In an effort to be part of a unified information space of South East Europe, Kosovo has to innovate and invest in education and research in the field of information and communication technologies. On the way of the knowledge society it is still necessary to reduce the digital gap, expand the set of services and make central system and portal for electronic administration. Similarly, in the context of the special environment of Southeast Europe, authors have identified three key priorities: a unique information space, innovation and investment in ICT research and education and inclusive information society (information society for all). This is precondition that enables the creating an ICT based Environment that supports creativity, Innovation and Intrapreneurship. Positive samples of the paper can be useful to be implemented within SEE countries, and as an impact, the contribution of the paper will be shown as a possible model of managing and motivating an environment that supports Innovations through creativity.
\end{abstract}

Keywords: ICT, Intrapreneuring, Innovation, Creativity, SEE, Environment, Intrapreneurship, Entrepreneur

\section{Introduction}

Today's competitive and ever-changing business environment requests responsible and well educated management, which are prepared for the situations of the demanding market situations. One important way to correspond to an increasingly changeable market situation is to prepare the ICT and Cloud infrastructure to encourage the innovation and to create ability conditions for innovation, entrepreneurship and the motivation for a category of employees: Intrapreneuring.

ICT infrastructure, Cloud computing may and should help entrepreneurs and intrapreneurs in enterprises to achieve competitive advantage through innovation and creativity.

With innovation and creativity intrapreneurs transform an idea into a profitable venture, but all along operating within the organizational environment. Intrapreneurs are no less then entrepreneurs who follow the goal of the organisation rather than their own.

An 'Intrapreneur' is an individual in charge with pushing through innovations and creativity within an organization, in an entrepreneurial fashion.

Intrapreneurs are the best people of every company who manage to turn your ideas into added value for the company.

Intrapreneurs are the persons that are largely visionary, and are motivated from within themselves with the challenge of a strong sense of what is required for a firm, not only the efforts of our own progression through the hierarchy of the company. 
This is the person who takes great personal risk in terms of missed time and wages efforts to overcome the obstacles placed in the organization.

Characteristics of Successful Entrepreneurs are:

- The desire for accountability. The entrepreneur feels a deep responsibility for the project that started. He wants to control their own resources and use these resources to achieve these objectives.

- Willingness to moderate risk. Entrepreneurs are not eager to indulge in risk, but are willing to moderate calculated risk.

- Confidence in their ability to succeed. Entrepreneurs typically have great confidence in their ability to succeed. They are trying to be optimistic about their chances for success.

- The desire for quick response. Entrepreneurs enjoy keeping their jobs, and they want to know that they can quickly and independently make business decisions.

- High level of energy. Entrepreneurs are much more energetic than ordinary people. This energy can be a critical factor for starting their own businesses.

- Orientation towards the future. Entrepreneurs have a well-defined sense of finding an opportunity. They look forward to, and are less burdened with what they did yesterday, and more by what will work tomorrow.

- Skill in organizing. Entrepreneurs know how to connect the right people to accomplish a specific task. The effective combination of people and activities allows companies to transform their vision into reality.

- Desire to succeed over the desire for money. Wrong assessment is that the entrepreneurs are guided only by the desire to gain money. On the contrary, the desire for success in the enterprise in the first place, and the money is just a way to measure achievements.

Some additional characteristics of successful entrepreneurs are:

- Entrepreneurs like making money, as opposed to people who earn money to be able to do what they want,

- Entrepreneurs are bigger dreamers than other people,

- Entrepreneurs are focused on success,

- Entrepreneurs have a restless spirit. They are often impatient with people, in meetings, in various situations,

- Entrepreneurs are doing more than most people; sometimes they do not know whether they work or play,

- Entrepreneurs in danger look different from most people,

- Entrepreneurs are social, when necessary. Otherwise, they are usually solitary soul,

- Entrepreneurs are very proud and thus they are more easily upset and offended than other people,

- Entrepreneurs have expressed the spirit of competition,

- Entrepreneurs show less tolerance for the office rules, gossip and for parlour conversation.

'Intrapreneurship' is an entrepreneurial way of thinking and acting at a work place. When most individuals hear the word innovation, they think of cutting edge advancements in new products, service and technology. It is not only a buzz word, but it is a way of life in many successful organizations. Innovative organizations tend to be industry leaders in their market, trying to achieve first to market strategies in the latest and greatest of new products and new ways to maximize the customer experience. Indeed, innovation does not come without risks and uncertainty. But when you weigh the potential benefits that can be so great ,most organizations are willing to assume the associated risk of innovation.

\section{Research and Observation}

In the research paper, the benchmark was awarded to several employees of businesses in Kosovo enterprise and theoretical models which are foreseen in similar cases. A qualitative study was conducted with senior and middle management of several SMEs. A questionnaire was designed, in order to assess the characteristics mainly of entrepreneurs. Responses were analyzed with standardized tools of multivariate statistics. 


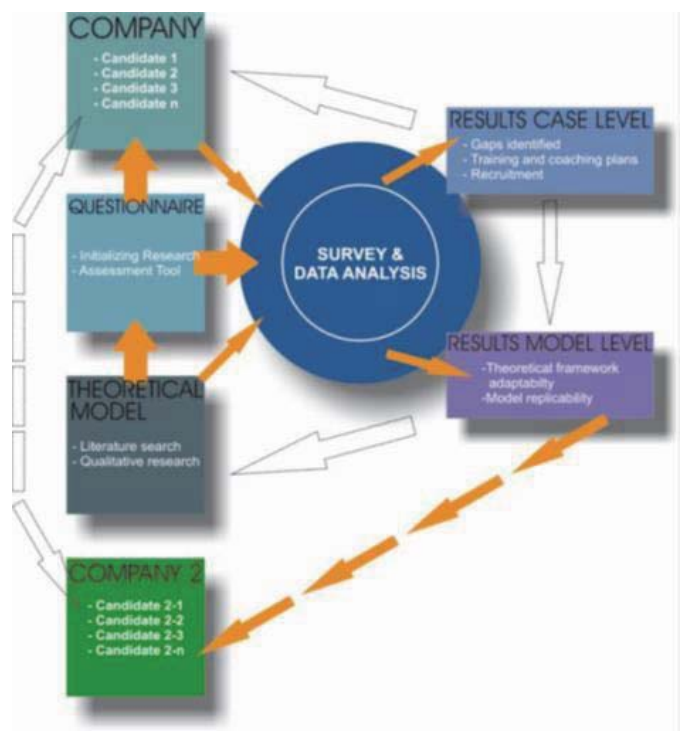

Figure 1: Methodology of survey and Analysis

On a particular case in Europe it is rapidly being embraced the adopting phrase of "fade and fashion" as a motivation for managers and employees to engage in to creativity so that the Organisation benefits in whole. Therefore it is crucial that managers organise the projects and listen and encourage the employers to get involved with their creativity and get out from their "comfort zone" and start thinking out of the box.

The ever growing demand in product life cycle with rapid change of rate of technology changes should keep managers always trying to keep up with the customer demand and understanding the product life cycle. The product life cycle rate has in those industries where technological change rate is fast decreased. As an example in a car industries and retail company's the technological innovation and design creativity has brought the product life cycle to a very fast pace, (an outdated car-models for example),all due to innovation and creativity in industries such as IT, semiconductors and such.

While this industries have an even faster, rapid, change of the product life cycle. On the other hand, some industries where the technological change is slow, i.e. electrical cable producer, the product change cycle is also slow. demand.

Those organisation that embrace change and have those changes in place at time, can keep up with the customer

ICT infrastructure offers a range of technologies to efficiently run organizations. These services are essential to the daily work of an organization and necessary for the effective delivery of services.

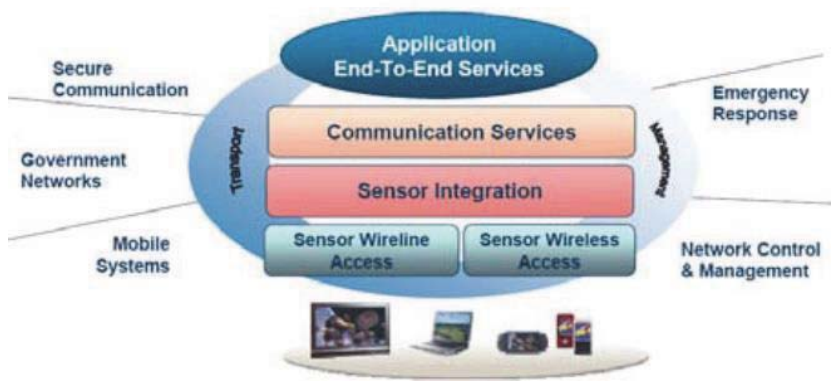

Figure 2: Modern Communication Infrastructure that supports innovation 
Innovation execution can be a source of enormous strength, and sustained success. An ICT based Environment that supports creativity, Innovation and Intrapreneurship in Kosovo and SEE Countries should posses an Infrastructure shown in the figure bellow.

Modern Communication Infrastructure should support Applications, Networks and terminal equipment

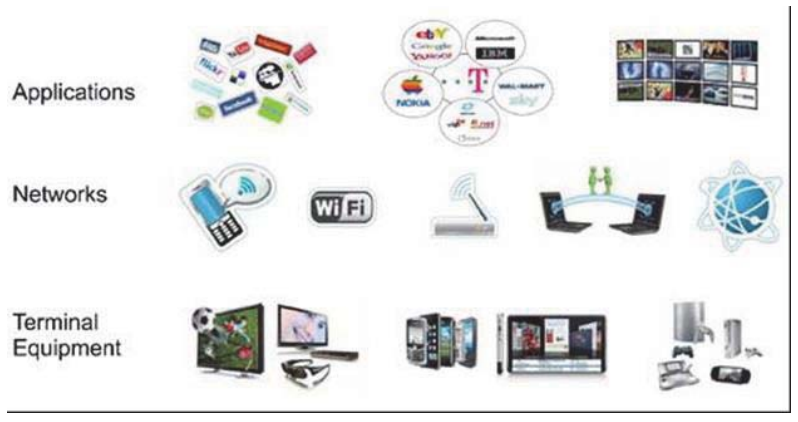

Figure 3: The telecommunications business context today broadband Internet, multimedia, IT services etc.

Source: Contribution from the authors

\section{Cloud Computing as an Opportunity for Innovation and Entrepreneurship}

Cloud computing is a model of delivering IT services that allows easy access at the request of the end user to allocated IT resources (common and configurable). Most often, it is a virtual network, application, data storage system, server or specific IT service.

These resources can be activated and deactivated immediately, with minimal human intervention on the side of service providers.

Basic characteristics are:

- $\quad$ Self-service users

- Independence from location

- The grouping of IT resources

- Rapid elasticity

- Measurable consuming services

There are 3 models of Cloud services:

- Software as a Service (SaaS)

- Platform as a Service (PaaS)

- Infrastructure as a Service (laaS)

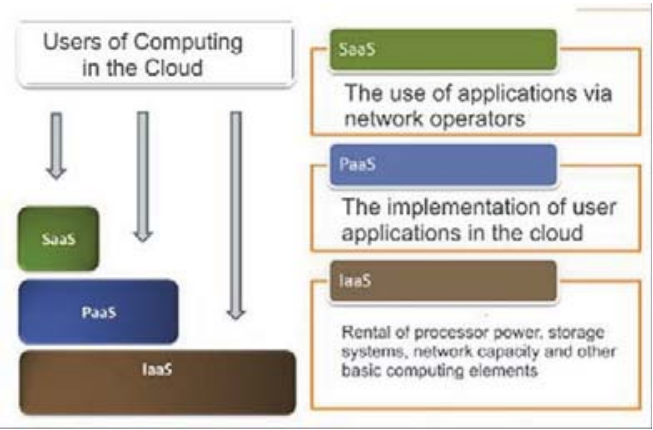

Figure 4: The architecture of a single cloud environment, the concept of shared infrastructure and definitions Source: Contribution from the authors 
There are 4 delivery models:

- $\quad$ Private cloud Private Cloud

- Community cloud-shared cloud

- Public cloud Public cloud

- Hybrid cloud Hybrid cloud

Opportunities, challenges and possibilities of Telecom operators in the market of cloud computing are shown in the following table:

\begin{tabular}{|l|l|l||}
\hline Opportunities: & Challenges: & Possibilities: \\
\hline Telecoms control access to cloud & Lack of flexibility & acquisitions \\
\hline They know their customers & The innovative capacity & Affiliate ecosystem \\
\hline They have existing systems to pay & Gather the development of new products & Identification of new departments in private companies \\
\hline $\begin{array}{l}\text { They have importance in the customer } \\
\text { base }\end{array}$ & $\begin{array}{l}\text { The business model optimized for infrastructure } \\
\text { services }\end{array}$ & Openness to partners and developers \\
\hline Financial Strength significant investments & Size of existing business & The redesign of the sales model \\
\hline Data Centres & global competition & Interface to customers \\
\hline Confidence users & & $\ldots$ \\
\hline
\end{tabular}

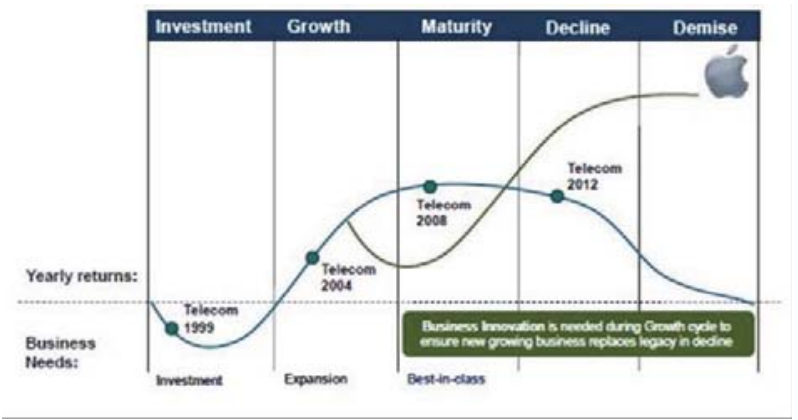

Figure 5: Telecom industry is still in the period of maturity but with a tendency to drop down

\section{Key Trends of Information Technology that Supports Intrapreneurship and Innovation}

Key trends of Information Technology that supports intrapreneurship and innovation are presented in the figure bellow:

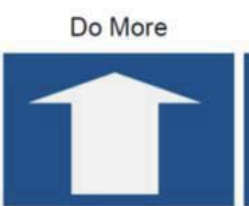

- End-to-end flexibility

- More services

- Lower operating expenditure (opex)

- Understand experiences
Faster

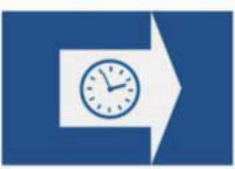

- Modularity

- Service-oriented architecture (SOA)

- Business process management (BPM) - APIs
At Lower Cost

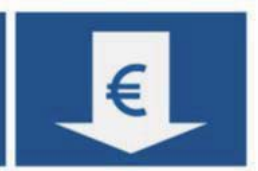

- Lean

- Virtualization

- Reuse

- Global delivery

- Outsourcing

- Open source

-Shared

Figure 6: Key trends of Information Technology that supports intrapreneurship and innovation Source: Contribution from the authors

In this regard in Kosovo will have to be taken the following measures: the obligation of computer literacy, to invest in ICT infrastructure in educational institutions and the creation of classrooms equipped with computers and Internet 
connections; the standards for minimum and advanced ICT skills will be improved education system by directly changing curriculums in our schools; by bridging the gap between different generations, will be organized professional education for ICT and with the private sector will be carried out activities on harmonization of ICT knowledge, as well as provision of programs for training throughout life; the research in the region; through the development of academic and research networks and better connections between researchers and institutions.

\section{The Drivers of the Development of ICT and Broadband Networks in Kosovo and SEE}

A comparison of the development of the ICT infrastructure of Kosovo with SEE-8 in 2013, is shown in the figure 3, presented bellow.

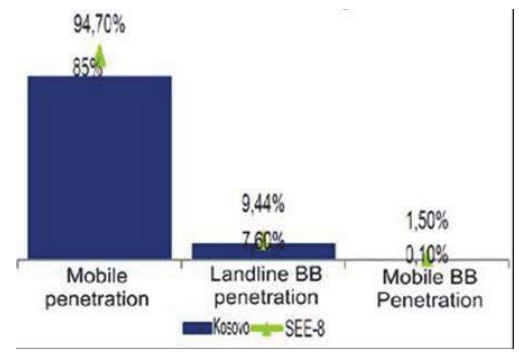

Figure 7: A comparison of the development of the ICT infrastructure of Kosovo with SEE-8 in 2012.

Source: Contribution from the authors

The European Union has set a BB agenda where it is planned that by $202050 \%$ of households have a $100 \mathrm{Mb} / \mathrm{s}$.

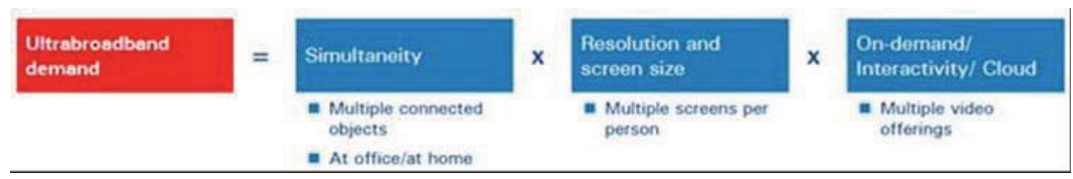

Figure 8: Broadband demand

\section{Balanced Model for the Achievement of the Desired Goal for ICT Infrastructure that Supports Innovation and Entrepreneurship}

Balanced Model for the achievement of the desired goal for ICT that supports innovation and Entrepreneurship is presented in the figure bellow:

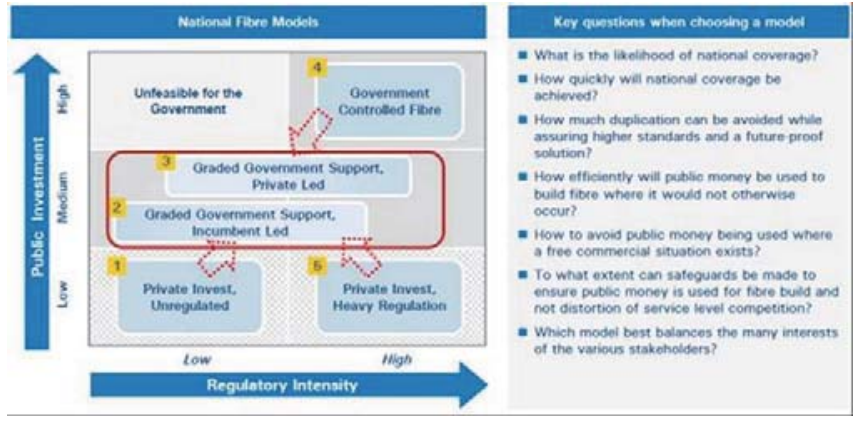

Figure 9: Balanced Model for the achievement of the desired goal for ICT that supports innovation and Entrepreneurship Source: Arthur D. Little - International Management Consulting Firm 


\section{Conclusion}

The Model of Cloud and ICT Infrastructure in Kosovo that supports the innovation should enable the necessary conditions for development of:

- $\quad$ Telecom 2.0

- Cloud Computing

- Portfolio of Services

- $\quad$ Management with IT Infrastructure

- Operating Models and Challenges

- Partnerial Eco System

As part of the priorities authors have specified three infrastructure needs, to be realized in Kosovo as follows:

- Creation of a unified information space, which aims to create an open and competitive market for information society and media services.

- innovation and investment in ICT research and education should establish measures that will aim to accomplish the creation of ICT infrastructure, with the aim of ensuring greater profit.

- Inclusive Information Society that aims to promote equal opportunities for all in the way of the knowledge society and overcome the digital divide.

\section{References}

Cooper, A.C., Markman, G.D., \& Niss, G. (2000). The evolution of the field of entrepreneurship. In G.D.

Dess, G. G., Duane R. Ireland, Shaker. A. Zahra, Steven. W. Floyd, Jay J. Janney, Peter J. Lane. (2003): Emergin Issues in Corporate Entrepreneurship, Journal of Management 29 (3), 351-378.

Beqiri Edmond, Interneti - komunikimet kompjuterike, IOM; International Organization for Migration; Dukagjini; UP 2002

Beqiri Edmond, Bazat e informatikës, University of Prishtina; Universiteti i Prishtinës; UP 2006

Harry E. Burke, Automating Management Information Systems: Principles of Barcode Applications, Thomson Learning, ISBN 0-44220667-4

Hickins M. (1999), "Xerox shares it's knowledge", Management Review, Vol-88, No. 9, pp.40-5.

Meyer, G.D. \& Heppard, K.A. (2000). Entrepreneurship as strategy. Thousand Oaks, CA: Sage Publications.

Morris, M.H., Kuratko, D.F., \& Covin, J.G. (2008). Corporate entrepreneurship and innovation. Cincinnati, OH: Thomson/SouthWestern Publishers. 